\title{
Folkloristic Contributions towards Religious Studies in Estonia: A Historical Outline ${ }^{1}$
}

\author{
ÜLO VALK \\ University of Tartu
}

\begin{abstract}
The article outlines the historical development of the study of folk religion and mythology in Estonian scholarship. It shows how the changing ideological and political context and formation of folkloristics as an autonomous discipline have shaped the construction of its object - Estonian folk religion. The roots of conceptualizing folk religion as an inherited set of survivals of heathendom lies on the one hand in the systematic work of the Lutheran Church in strengthening the Christian worldview by eradicating superstitions. On the other hand, the ideology of national awakening depicted Estonian folklore as a huge and valuable reservoir of pre-Christian traditions, including the oldest survivals of Finno-Ugric cultural heritage. Later, during the period of Soviet occupation, Marxist evolutionary views contributed towards considering folk religion as an archaic form in human development; in addition, anti-clerical ideology reinforced a stereotype of the people's adherence to their indigenous religion and contrasting this with Christianity as an alien ideology of oppression. The last part of the article discusses scholarship after the re-establishment of Estonia's independence in 1991, as the former ideological framework slowly faded away and new conceptual developments emerged.
\end{abstract}

Keywords: folk religion, vernacular religion, Estonian folklore, history of folkloristics

From a historical perspective, the roots of religious studies in Estonia are in Protestant theology and in the missionary endeavors of the Lutheran Church. Throughout the 18th century the ethnic Estonians remained culturally distant from the Baltic-German elite and were seen as the others, as backward peasantry and a simple workforce for the manors. Since their universe seemed weird, it needed ethnographic documentation, observed from above, as is found in the monumental work Topographische Nachrichten

1 This research has been supported by the European Union through the European Regional Development Fund (Centre of Excellence, CECT) and by the Estonian Ministry of Education and Research (Institutional Research Project IUT2-43). 
von Lief- und Ehstland ('Topographic reports from Livonia and Estonia', 1774-1789) by August Wilhelm Hupel (1737-1813). Hupel, a Lutheran pastor, notes that the superstition (Aberglaube) of the Estonians 'derives partially from the pagan period and partially from their onetime ill-understood teaching' (Hupel 1963, 84), meaning the earlier Catholic era. Interpreting its folkloric survivals as superstition and idolatry, and associating them with pre-Christian beliefs and practises, became a stereotype that was reinforced in later scholarship, determining the prevalent view of folk religion as a sphere which can be characterized as syncretic but at the same time controversial and split by dichotomies.

In 1802 the university was reopened in Tartu ${ }^{2}$ under the name Kaiserliche Universität $z u$ Dorpat, offering academic education not only for the German students but for ethnic Estonians as well. The emergence of intellectuals of Estonian origin stimulated the opening of dialogue between the two autonomous cultures of the elite and of the rural population. The first educated Estonians blended into the high German society, however, while maintaining some of their ethnic otherness as carriers of indigenous knowledge. German Estophiles and Estonian intellectuals both contributed to the development of Estonian literature, but the two cultural spheres remained distinct and their boundaries were even reinforced. A view from the outside - from the Baltic-German perspective - shaped the construction of Estonian mythology and realm of folk beliefs as inherently different from the religion of the German nobility, which set the social norms and standards of the Christian faith. The current article discusses the development of the study of Estonian mythology and folk belief in the context of historical, ideological and political changes, and shows how folkloristics has contributed towards constructing the notion of Estonian folk religion as a distinct cultural domain and as an object of studies. As the conceptual framework of research was formulated quite early and has been historically persistent, however, it would be difficult to discuss recent developments without a historical introduction. My goal is not to give a detailed survey of scholarship but to outline some general developments of research and conceptual changes.

\section{Steps towards Academic Folklore Studies in Early 19th Century}

The German philosopher Johann Gottfried von Herder (1744-1803) - pioneer of folklore studies and advocate of nationalism - had a strong impact on the

2 Tartu has been known by several names during its history, in different languages and/or under different rulers. Its German and Swedish name was Dorpat. 
thinking of Baltic-German Estophiles. He wrote some of his early seminal works in Riga, where he lived during 1764-1769 and became acquainted with the oral traditions of Estonians and Latvians, which most probably influenced his ideas about folklore (Undusk 2008, 108-9). One of Herder's fundamental theses was his pluralism, his rejection of universal values and his belief in the uniqueness, individuality, and incommensurability with one another of different civilizations - each to be seen as an 'organic' whole (Berlin 1977, 208-9). His emphasis on the uniqueness of each language and heralding the equal rights of ethnic communities prepared for the emergence of Estonians and Latvians as nations. Instead of being described together in social terms as representatives of the socially lowest, rustic strata, they now acquired their distinct national identities. The Baltic-German scholar Garlieb Helwig Merkel (1769-1850) described the historical Christianization of Estonians and Latvians as a violent turn, leading to their downfall to serfdom (Undusk 2008, 106). In contrast to other Baltic-German scholars, who saw the local peoples as mere objects of history, as local savages, whose Christianization had brought them salvation, Merkel regarded them as historical subjects, whose high culture, comparable to the ancient Greek civilization, had been destroyed by barbarian invaders (Annist 2005, 404). Merkel praised the Estonians 'for preserving steadfastly their beliefs, fairy-tales, ancient memories and sacred places, which have still survived the devastating flow of miserable centuries' (Annist, ibid.). Kristjan Jaak Peterson (1801-1822), an Estonian poet and writer, translated Christfried Ganander's (1741-1790) Mythologia Fennica from Swedish into German, and added his own comments about parallels in Estonian mythology. He rearranged the material and presented it as an organized and hierarchical system (Järv 2001, 178-9). Peterson's adaptation of Ganander's book laid the foundation for the creation of an Estonian pantheon of deities with literary origins, later characterized as 'pseudomythology'. In addition, his observation that Finnish and Estonian mythologies were closely related introduced Finnish-Estonian comparisons as a growing trend in later scholarship.

In 1838 the Learned Estonian Society (Gelehrte Estnische Gesellschaft) was founded, and its statutes formulated its goals as being 'to further knowledge of the past and present of the Estonian people, its language and literature, as well as the country settled by the Estonians' (Laar 2010, 225). One of its founders was Friedrich Robert Faehlmann (1798-1850), a medical doctor and alumnus of the University of Tartu, whose mother tongue was Estonian (Laugaste 1963, 342). He became a key-figure in the Estonian national movement, who devised the basic storyline of the national epic Kalevipoeg, 
which was later versified by Friedrich Reinhold Kreutzwald (1803-1882). Although composed in German, Esthnische Sagen ('Estonian legends') has special status in Faehlmann's literary output as an early masterpiece of Estonian literature, blending folklore and fiction. Faehlmann contributed greatly to the new Estonian mythology by composing elaborate plots about the creation of the world and about pagan deities. In his introduction to the legends, Faehlmann noted: 'The Estonians have preserved much of their former memories, songs, and legends as something holy; a few years ago it was still possible to find traces of ancient idolatry. However, since Pietism has started to penetrate deep into the life of the people, all now seems to be in decay. Singing folk songs and telling legends have become forbidden for the people; moreover, the last survivals of worship of pagan deities are being destroyed and there is no chance for historical research' (Faehlmann 1999, 36). Such observations were in full accord with the paradigm of the rapid disappearance of folklore, which prevailed in early scholarship. Postulating the inevitable loss of ancient traditions due to the predominant Christian religion prepared the way for large-scale folklore collecting that started half a century later.

In 1866, Faehlmann's legends were for the first time translated into Estonian, and published on the front page of the popular newspaper Perno Postimees under the title 'A couple of words about the ancestors of the Estonian people'. An anonymous article on the front page of the newspaper emphasized the fundamental dichotomy between Christianity and pagan religion, described the ancient Estonians as worshippers of alien gods, and compared them with 'contemporary poor pagans of Africa and Asia' (Perno Postimees 1866, 1). The article called the main god of Estonians Jummala or Tara, and then proceeded to Faehlmann's text, introducing several neomythological deities, such as Wannemuine, Ilmarine and Lämmeküne (ibid.). (Whereas jumala ['god'] is a Baltic-Finnic word, which had been taken over to denote the God of Christianity, $\mathrm{Ta}(\mathrm{a})$ ra's background in oral traditions is doubtful. The deity was popularized in literature and was folklorized in the late $19^{\text {th }}$ century.) In 1867 Carl Robert Jakobson (1841-1882), a journalist and leader of the national movement, published his 'School Reader' (Kooli lugemise raamat), which was widely used in Estonian schools and was reprinted fifteen times during the next forty years. In this reader Jakobson popularized the Estonian neomythology of Faehlmann's legends and of Kreutzwald's epic Kalevipoeg. Jakobson presents Jumal as the main god of the ancient Estonians; three minor deities were Ukko, the god of thunder, Wanemuine, the song god, and Taara, the war god. Jakobson wrote: 'These 
gods were still worshipped, when Estonians had become Christians by name only, until Luther's reformation reached our country and defeated the darkness' $(1867,156)$.

These ideas about pagan religion spread widely in Estonian society and laid the foundation for the views of 20th-century scholars. Heathendom and Christianity were seen as polarized opposites, but their evaluation became ambivalent. On the one hand Christianity was seen as the liberating force that had saved Estonians from heathendom, but on the other hand it was also interpreted as the tool of foreign oppression, which had ended the Estonian golden age. Generally, early scholars acknowledged the importance of Christian conversion, but tended to overlook its role in generating folklore. Instead, they were looking for non-Christian beliefs and customs as survivals of the ancient religion. Folklore was not seen as a concomitant of everyday life, or as an expression of vernacular creativity, but as a huge reservoir of historical memories, a joint property of the whole Estonian nation. The Estonianization of folklore also prepared for the view that Estonian folk religion existed as an autonomous system, to be set alongside German, Swedish, Latvian and other folk religions, whose relations can be discussed in terms of influences and borrowings. Moreover, it was presumed that the Estonian mythology and world of folk beliefs had once formed a coherent and inherently ordered system, which could be restored and meticulously described.

\section{Professional Folklore Studies: From Systematic Collection to Research}

Jakob Hurt (1839-1907) was the leader of the national movement, and the most outstanding Estonian folklorist of the 19th century, who with the help of local correspondents collected oral traditions all over the country. As an initiator of a series of academic publications, such as Vana Kannel ('The Old Harp') and Monumenta Estoniae Antiquae, he is the founder of contemporary folkloristics. Hurt studied theology at the University of Tartu, and later took his doctorate in linguistics at the University of Helsinki and worked as a Lutheran pastor in Otepää and St. Petersburg. Whereas the vast majority of earlier authors who studied Estonian folklore had published their works in German, Hurt introduced academic writing about folklore in the Estonian language (Jaago 2005). His public appeal 'A couple of requests to the most vigilant sons and daughters of Estonia' was published in 1888 in the leading newspapers, and served as a questionnaire for collectors of folklore. It includes instructions for collecting data about 'old customs and 
observances' (vanad kombed ja pruugid) and 'old folk belief and superstitions' (vana rahvausk ja ebausk). Hurt published in the press one hundred and fifty six reports about his collecting activities, responding to his correspondents and giving them advice for further work. In repelling criticism of his fellow pastors against his interest in superstitions, he wrote:

Our work of writing down folklore (vanavara) is a work of research and science. Even the blindest customs of superstition must become the matter of research and science. Only then will it become possible to defy and defeat them, where necessary. Those who send superstitions to us are themselves free from superstitions. The superstitious do not write to us. The material collected will become a good remedy against all kind of blind hocus-pocus. Darkness will always be chastised if it is brought to light. Therefore, do not be afraid if you write down even terrible things from the memories of old times. (Hurt 1888, 1.)

Matthias Johann Eisen (1857-1934) was another pastor who started largescale collecting of folklore. He has usually been considered as Hurt's rival, who failed to reach high scholarly standards. Whereas Hurt's folklore collection exceeded 122000 pages, Eisen reached 90000 pages. Unlike Hurt, whose academic publications of folk songs were addressed to scholars, Eisen published multitudinous small books about folklore for a wide readership who read and wrote in the Estonian language (Kuutma 2005, 93). Kristin Kuutma notes that Eisen was 'driven by the idea of restoring the people's heritage by activating the collecting process through publishing' (ibid., 93-94). Indeed, Eisen and his folk books played a remarkable role in introducing the new era of Estonian folk religion at the end of 19th century, when literary and oral transmission merged and clear differentiation between the two became impossible. Eisen's contribution to Estonian folkloristics, which has been played down in earlier scholarship in comparison with Hurt's achievements, has recently found recognition (Kuutma 2005, Kikas 2013).

Eisen was also a systematic scholar of Estonian folk religion, and published four monographs: Eesti mütoloogia (1919) ('Estonian mythology'), Eesti unem mütoloogia (1920a) ('Recent Estonian mythology'), Esivanemate ohverdamised (1920b) ('Sacrificial rites of the ancestors') and Eesti vana usk (1926) ('Ancient Estonian belief'). As a compendium of Eisen's folklore collections and earlier scholarship, these works are a landmark in early research in Estonian folk religion, although their editorial standards remained low (see Tedre 1996). Finnish scholarship, such as Suomen suvun pakanallinen 
jumalanpalvelus (1894) ('The pagan cult of the Finnic kindred [peoples]') by Julius and Kaarle Krohn, and Suomalaisten runojen uskonto (1915) ('The religion of Finnish songs') by Kaarle Krohn, served Eisen as basic sources for comparative data and for arguments about the history of Estonian folk religion. Eisen also frequently referred to the Finnish Kalevala and the works of Eemil Nestor Setälä, though he forgot to include them in the bibliography. He used the Kalevipoeg as a source of the ancient mythology, although it had become clear that Kreutzwald 'had most regrettably not maintained the folk songs which he had used to compose the Kalevipoeg in their original guise' (Hurt 1989, 50). Methodologically, he reinforced the perspective that the proper context for research on Estonian folk religion lay in the folklore of other Finno-Ugric peoples. Thus, his bibliography lists the works of M. A. Castrén, U. Holmberg, V. Islavin, F. A. Hästesko, J. and K. Krohn, H. G. Porthan, A. V. Rantasalo, J. E. Rosberg, I. Smirnov, A. M. Tallgrén, M. Varonen and others (Eisen 1996, 178-84). Eisen also published the first comprehensive survey in Estonian of the Finno-Ugric peoples, languages and cultures, with his main focus on the Baltic-Finnic and Saami area (Eisen 1909, 1911). Although he emphasized the importance of the Finno-Ugric background, he also acknowledged the influence of Christianity on Estonian folk belief and customs, dedicating a special monograph to 'recent mythology', as he called vernacular Christianity. In the introduction to the book he noted:

Christianity brought many new ideas to our people, including saints who were to displace the ancestors' former mythic figures. Paganism did not disappear without trace, but more or less merged with Christianity, leaving its vestiges behind. (Eisen 1920, 5.)

In 1918 Estonia declared independence, and extensive reforms were implemented at the University of Tartu. Estonian folklore studies were now recognized as an academic discipline, and Walter Anderson (1885-1962) was invited to the new chair in Estonian and comparative folklore. As a scholar of folktales, he developed the geographic-historical school, but had a wide range of research interests, including folk belief and customs, chain letters and rumours. His student Oskar Loorits (1900-1961) became the most outstanding scholar of Estonian folk religion (see Västrik 2005). From 1920 onwards, he undertook regular fieldwork among the Livonians ${ }^{3}$ in Latvia,

3 Livonians: a population speaking a distinct Finno-Ugric language, who lived in the coastal areas of present-day Latvia. There were around 2,000 Livonian speakers in the beginning of the 20th century but later their number declined rapidly. 
and published three volumes on their folk religion; two of these volumes remained in manuscript, and were published posthumously (1926-1928; 2000a). The first three volumes on Livonian folk religion (altogether 832 pages) are a manifest of professional scholarship on folk religion, written in the Estonian language. Although Eisen's monographs on Estonian mythology and the work by Loorits were published at the same period, they represent two different eras and research standards. Eisen had gathered rich data, arranged it thematically and provided with comments, mainly drawn from the existing scholarship. Loorits avoided compilations but presented his own material in a coherent conceptual framework and analyzed it systematically, preferring complete recordings to short summaries or paraphrases of source material, such as we find in Eisen's publications. However, Eisen and Loorits also shared certain approaches, such as emphasizing the Finno-Ugric context. Loorits argued that the genuine roots of the Livonian traditions can be traced back to ancient Finno-Ugric culture, whereas Latvian influences are characterized as recent borrowings.

In 1927 the Estonian Folklore Archives (Eesti Rahvaluule Arhiiv) were founded in Tartu, and Loorits became their first director. Arranging the material, compiling indexes and thematic card files meant that a systematic typology of Estonian folk religion was created. This had a strong impact on future scholarship, as it has guided the researchers to perceive folk beliefs and customs as an internally organized body of heritage. Special card files were created of beliefs and customs about living and inanimate nature, about human beings, the folk calendar, folk medicine, dream omens, legends about supernatural creatures, and many other subtopics. Archival work turned the research interests of Loorits towards Estonian folk belief, and he published two comprehensive monographs Estnische Volksdichtung und Mythologie ('Estonian folklore and mythology' 1932a) and Eesti rahvausundi maailmavaade ('The worldview of Estonian folk religion') (1932b). The first is a survey of the history of folklore collecting in Estonia within the context of ethnic and cultural relations, and the main genres and topics of folklore, with the emphasis on folk beliefs. As an archivist, Loorits knew that not all the manuscripts of the Estonian Folklore Archives represented oral traditions, but that many had their background in book-lore and had essentially been composed as pieces of fiction. He started a prolonged struggle against literary mystifications of Estonian folklore and the related misconceptions, contrasting genuine folk traditions with the inauthentic 'pseudomythology', which had its roots in Peterson's translation of Ganander's work, Faehlmann's legends and Kreutzwald's epic Kalevipoeg. Loorits considered it as 
a fatal error that Estonian folk beliefs had been studied through the lenses of ancient and Germanic mythology, and argued that the whole world of personified gods and half-deities had no ground in true Estonian folklore (1932a, 39-40). Alongside the familiar dichotomy of 'Christian-pagan', a new powerful set of oppositions had now been created, which continued to guide Estonian folklorists until the late 20th century: 'authentic/ancient/ oral versus fake/new/literary'.

Loorits argued that the distinctive feature of Estonian folk religion is that man is in close relationship with nature, not as its ruler but as an equal partner - a belief which he found also among Finno-Ugrians in general and among other 'primitive peoples' (1932a, 42). He stresses the animistic traits of Estonian folk religion, and analyzes the beliefs about human psychology, life force, and a range of concepts of the soul (1932b). The bibliography of the book refers to works by Julius and Kaarle Krohn, Kustaa Fredrik Karjalainen and Uno Holmberg (Harva), revealing his orientation towards Finnish scholarship and his conviction that Estonian folk religion should be studied within the context of the cultures of the kindred Finno-Ugric peoples. Loorits' scholarly works are based on solid empirical material from the Estonian Folklore Archives, but as a polemical and socially oriented author, he often deviates from scholarly grounds to ideological and even moralist argumentation. Thus, the concluding chapter of his book Worldview of the Estonian Folk Religion bears the title 'Teaching of the Past for the Future', and characterizes the ancient Estonian mentality as tolerant, grounded in the principles of equality and chaste purity. Christianity, as it had been introduced by Germans, had caused its degeneration and a reorientation towards malevolence and evil (1932b, 105-107). Loorits' views about Estonian history have been characterized as Germanophobic; Anti Selart has formulated one of his basic standpoints as follows: 'The Estonians mentally belonged rather to the East than to the West, where for Loorits "West" meant the cultural sphere influenced by the Indo-Europeans, and the "East" stands not only for the Arctic and Siberian "nature peoples", but also for the ancient high cultures of Eastern Asia' (Selart 2013, 145). On these grounds Loorits idealized a genuinely harmonic and peaceful worldview among the Uralic peoples as 'thoroughly monistic and based on the principles of equality and parity, which is not confined to humans only but is extended to the whole of nature' (Loorits 2000b, 319).

We can see that the concept of Estonian folk religion as a body of heritage which had been constructed during the 19th century within the context of nation-building remained ideologically and politically charged. The 
sources of folk religion were not only documents about the past culture, but also tools for nation-building. The following era of Soviet occupation, and the establishment of Estonian scholarship in exile, only continued this trend that linked folk religion (and folklore in general) with crucial issues of maintaining and developing national identity. This tendency was more pronounced in the works of scholars who worked abroad, but in a concealed way, linking folklore with national resistance and maintaining Estonian identity continued in Soviet Estonia as well.

\section{Scholarship in Exile and in Soviet Estonia}

The Second World War ended Estonia's first period of political independence, and interrupted the development of folkloristics and religious studies. When the Soviet army invaded Estonia in 1944, several scholars fled the country. Oskar Loorits settled in Sweden and continued his work at the dialect and folklore archives (Landsmals- och folkminnesarkivet) of the University of Uppsala. As he had brought with him abundant source material from the Estonian Folklore Archives, he was able to complete his life's work, and published three extensive volumes of Grundzüge des estnischen Volksglaubens (1949; 1951; 1957), altogether nearly 1800 pages. This monumental work is a systematic survey of thematically arranged folk beliefs and customs from the collections of Estonian Folklore Archives and from printed sources. It is also a grand retrospective vision of the historical development of Estonian folk religion in its multiple layers, starting from the oldest, Uralic period 4 or 3 millennia BCE. Loorits' main goal, however, is to outline the basic features of Estonian spirituality (Geistigkeit) in the light of folk religion and folklore, and 'to comprehend the spirit of the people (Volksgeist) as an organic whole' by applying synthetic methods (1949: VII). Throughout the study he tries to distinguish the original elements from borrowings, and if something appears to be a loan, he loses interest in studying it further (Annist \& Moora 1965, 507). August Annist and Harri Moora, who published a review of the monograph in Soviet Estonia, criticized its weaknesses, some of which were due to 'the idealistic general conception' of the project, but they also acknowledged it as 'the most complete and systematized body of material of the worldview and spiritual heritage of our people' (ibid. 508). Annist and Moora note that an additional value of the work for Soviet scholars lies in the fact that it is 'directed against the clerical outlook on religion and history' (ibid.). Indeed, several of Loorits' works seem to be driven by anti-Christian sentiment, as he talks about the degeneration of 
Estonian mentality after Christianization. On the other hand, Loorits saw the early Byzantine-Orthodox influences, before the German and Danish conquest, in a positive light and his negative attitude towards the medieval and later developments was driven by his generally Germanophobic views (Selart 2013, 149).

Loorits' magnum opus was reviewed by several outstanding scholars, including Lauri Simonsuuri, Reidar Th. Christiansen, Åke Campbell, and Will Erich Peuckert, and by Gustav Ränk, who acknowledged the Grun$d z \ddot{u} g e$ as a landmark of Estonian scholarship, but criticized the hypothesis about the Uralic spirituality of Estonians as an empirically ungrounded misconstruct (Ränk 2000). Gustav Ränk (1902-1998) belonged to the same generation of Estonian scholars as Loorits did. They both had left Estonia in 1944 to escape the Soviet invasion. Ränk became an internationally leading ethnologist in Sweden, where his research interests expanded to North-Eurasian folk cultures, vernacular architecture and folk religion (e.g. 1949; 1996; Runnel 2000). Ivar Paulson (1922-1966) was an Estonian scholar of the next generation, who wrote his dissertation in ethnology at the University of Hamburg. Later he continued his studies at the University of Stockholm (1952-56), where he became the first Estonian who had received thorough and systematic academic preparation in religious studies (Ränk 1997). Guided by Professor Ernst Arbmann, Paulson wrote his comparative phenomenological dissertation on the soul concepts of the North Eurasian peoples (1958). Paulson also published works on the guardian deities of animals and hunting rituals in North Eurasia, and on ancestor worship and beliefs about man and afterlife among the Finno-Ugrians. He wrote comprehensive overviews of Siberian and Finno-Ugric religions for the series Die Religionen der Menschheit (1962a; 1962b). Whereas several earlier scholars of Estonian folk religion started from local folklore and looked for Finno-Ugric parallels, Paulson's scholarly path was the opposite. Paulson approached the Estonian material from his perspective as an expert on FinnoUgric religions, and had prepared a monograph Old Estonian Folk Religion (1966), which was published soon after his untimely death. As he had no access to the collections of Estonian Folklore Archives in occupied Estonia, he relied on the works of Loorits and other authors. In 1971 the English translation of the book appeared, becoming the most comprehensive study of Estonian folk beliefs ever printed in English. Paulson conceptualized folk religion 'as a separate organic whole whose different complexes (in terms of phenomenology of religion) and whose aggregate whole of phenomena and characteristics are closely tied, interwoven, and fused with each other' 
$(1971,207)$. He saw a sharp dividing line 'between the religious convictions and customs of the common people and the teachings and the religious cult of the ruling classes, which are fixed, canonized, and finally dogmatized in writing' (Paulson 1971, 56). Although he noted the strong influence of official, Christian religion on Estonian folk religion, he preferred to study its 'ancient' elements, following the traditions, as had been established by Hurt and Loorits.

Thanks to the works of Loorits, Ränk and Paulson, there was a remarkable development in the study of Estonian folk religion in Sweden. Research in Estonia was retarded, and in 1966 August Annist (1899-1972) published a critical article about the study of folk religion in Soviet scholarship (Annist 1966). He noted that progress had been made elsewhere in Soviet Union, for example in Russia, but that in Estonia research on folk religion had been neglected. He stressed that the relevant knowledge was indispensable for all scholars who study the past $(1966,458)$. In order to give ideological weight to his arguments, he pointed out that this kind of work would improve the quality of atheist education (Annist 1966, 462). Annist saw the lack of interest in folk religion as an obstacle for folklore studies, as the two fields are closely intertwined. He acknowledged the works of Ivar Paulson as useful study materials for students and for providing guidelines for future research, and remarked that his studies confirmed that the 'genetic relationship of the old Estonian folk culture should not be looked for in the Western but rather in the Eastern world' $(1966,464)$. Annist called attention to recent works on folk religion and mythology by Gustav Ränk, Martti Haavio, Iivari Kemppinen, Matti Kuusi and Lauri Simonsuuri, and regretted that Soviet Estonian scholars had not made comparative studies on the Eastern Finno-Ugric or Siberian peoples. He praised Lauri Honko's Geisterglaube in Ingermanland as a remarkable folk psychological and functionalist dissertation, which is 'interesting and useful for folklorists, psychologists and sociologists' (1966, 467). Annist also mentioned that in 1965 under Lauri Honko's editorship the journal Temenos had been launched in Turku as a joint project of Finnish, Swedish, Danish and Norwegian ethnologists (ibid.). Annist's public recognition of Western scholarship is remarkable, and shows that in spite of political isolation these recent works had reached Estonia and had a potential of positive impact on local research.

However, Annist's programmatic article had practically no effect on the study of folk religion in Soviet Estonia. Among the topical issues of folklore studies were continuous fieldwork, arranging material, creating typologies and indexes, and preparing academic publications of traditional folklore. 
Ülo Tedre discussed folk religion briefly in the introductory chapter of the first volume of the academic history of Estonian literature, emphasizing its animistic features, abundant magical practices and some traits of degenerate shamanism. In his view, the ancient beliefs in Estonia were widely retained until the 18th and 19th centuries, and the Christian influences were minimal and mainly concerned some terminological changes (1965, 21-26). Tedre also notes that in Soviet folkloristics folklore is conceptualized as oral and artistic production, while the rest of traditional intangible heritage (such as religion and customs) belong to the discipline of ethnography (Tedre 1965, 26). However, folk religion maintained its position in folkloristic scholarship, although it was marginal. Eduard Laugaste (1909-1994), who was the leading folklorist at Tartu State University (as it was known during the Soviet period) published early records of Estonian folklore from medieval and early modern sources, including some ethnographic data about beliefs and customs (1963). His study-book for students Estonian folklore includes a small chapter on animism, which also covers the topics of magic, taboo and totemism (1977, 41-47). Folklore students at Tartu State University were encouraged to write their graduation theses on some aspect of folk religion, such as folk calendar and customs or supernatural beings in legends, but very few professional folklorists continued this kind of research. Eha Viluoja studied legends and beliefs about the restless dead and related customs in traditional Estonian folklore (1987); Mare Kõiva did research on Estonian folk medicine and charms. A remarkable achievement was the publication of the commentated anthology of the Estonian folk calendar in eight volumes - a work started by Selma Lätt but mainly carried out by Mall Hiiemäe (Lätt 1970; Hiiemäe 1981-1999, 1998).

Soviet folkloristics was inherently philological, conceptualizing folklore as an early phase of artistic development, which precedes the more advanced stage of written literature. Expressive forms of folk religion generally did not fit in this narrow, poetic definition of folklore and were left for ethnographers and archaeologists to study. As a rare example of an ethnographic approach, Paul Hagu's work on the agrarian customs and beliefs of the ethnic group of Setus is worth mention (Hagu 1975). He defended his dissertation at the Leningrad branch of the N. N. Miklukho-Maklay Ethnographic Institute in 1983. In 1990 Aino Laagus (1944-2004) defended her innovative dissertation on structure and semantics of Estonian legends about forest spirits, developing the method of situation analysis for the systematic scrutiny of stories about supernatural encounters (Laagus 1974). This method of processing large amounts of texts for drawing general conclusions offered 
a rigorous model for textual analysis of legends and other folk narratives (see Jaago 2009). Some archaeologists studied pre-historic animistic beliefs in Estonia on the basis of Neolithic artefacts (Jaanits 1961) or interpreted the conservative burial customs as a form of resistance to Christianity (Selirand 1961). The Marxist view of religion, as a typical phenomenon of more primitive periods of human civilization, harmonized with the preference of folklorists to study the ancient, pre-Christian beliefs. Taken altogether, the ideologically biased view towards religion as a hindrance to social progress, and the established stereotype that the essence of folk religion is a complex of pre-Christian survivals and that its practise was a form of resistance to Christianity, were factors that retarded scholarship. In addition, the Soviet model of disciplinary affiliation deprived folklorists of folk religion and assigned it to ethnographers, who were not eager to pick it up but focused instead on material culture.

\section{New Beginnings and Expanding of Scholarship}

In the late 1980s, the politics of perestroika and glasnost, and the weakening of censorship, introduced the historical changes that led to the collapse of the Soviet empire and the re-establishment of the independence of Estonia, Latvia and Lithuania. In 1990 an international conference of folk religion was organized in Tartu, dedicated to the $90^{\text {th }}$ anniversary of Oskar Loorits' birth. Remarkably, the forum was called 'Folk Belief Today', signaling a shift towards conceptualizing folk religion as a living phenomenon, not a mere survival or an object of retrospective research. The main organizer of the conference was Mare Kõiva, who during the same year had defended her dissertation on Estonian charms. In 1990 she formed a research group on folk religion and folk narratives at the Institute of Estonian Language and Literature. In 1994 Ülo Valk defended his dissertation on the image of the Devil in Estonian folk religion in the context of Christian demonology and international folklore. Its slightly edited version was later published in Folklore Fellows' Communications (Valk 2001). The work reveals the hardships of reviving research on folk religion, as it proceeds from the old comparative historical traditions in Estonian folkloristics. It is a phenomenological and statistical study, based on the collections in the Estonian Folklore Archives, and sees folk religion through the philological paradigm, leaving its social dimension in the background. Unlike earlier research, Valk does not emphasize the Finno-Ugric context, but links Estonian folk religion with the world of Western Christianity. 
One of the legacies of the Soviet period was the generally miserable condition of academic libraries, although many books by Finnish folklorists and a few series, such as Folklore Fellows Communications or Temenos had been available even in Soviet times. The academic training of Estonian folklorists, including the author of the current article, was not sufficient to follow the contemporary, contextually oriented developments and theoretical currents in international scholarship. It was necessary to break out from this international isolation, but the lack of funding was overwhelming. In 1992 the Nordic Institute of Folklore (NIF) held a conference 'Recent Issues in Folkloristic Research in the Nordic Countries' in Turku, presenting invitations to many Estonian, Latvian and Lithuanian folklorists to participate in the event (see Anttonen \& Kvideland 1993). ${ }^{4}$ Whereas Estonian folkloristics had been relatively homogeneous as regards its philological and retrospective approach, the conference revealed Nordic folkloristics as a seemingly unbound world of scholarly freedom and diverse methodologies. Instead of looking back into the past, synchronic approaches to culture and its multiple expressions dominated. The encounter with treating folklore as a dynamic social phenomenon, and the emphasis on theoretical reflection, were both puzzling and inspiring. However, the regenerative power to revive research in folk religion did not come solely from foreign sources, but depended equally on native traditions. Estonian scholarship in exile, and the work of local scholars who had not been recognized in the Soviet period, became influential. Uku Masing (1909-1985) was one of these unrecognized intellectuals who had stayed in Estonia, and sometimes participated in the workshops and conferences of folklorists. He was a theologian, philologist, poet and philosopher who had taught at the Faculty of Theology, University of Tartu before the Second World War. In the Communist reforms he lost his job at the university and lived as a private scholar in Tartu, with his manuscript works circulating as typewritten copies. In 1989 the journal Akadeemia, which had been closed in 1940 by the Soviet powers, published its first new issue, including the first part of Masing's extensive treatise 'On the mind of the peoples of sky-elk or a word on boreal orientation', which was continued in the next three issues (see Masing 2004). Masing treated the Estonians and other Finno-Ugric peoples as carriers of an indigenous boreal mentality, contrasting this mindset with the Indo-Germanic world view, which he argued is rooted in binary oppositions. In 1995 Masing's Estonian Religion was published, based on the lectures that he had delivered

4 The main organizers of this conference were Pertti Anttonen, Gun Herranen (both research secretaries of NIF) and Reimund Kvideland (director of NIF). 
between 1933 and 1940. In this monograph Masing discusses some aspects of Estonian folk religion, such as folk psychology, the afterlife, and beliefs about fairies, in the context of Finno-Ugric religions. In 1990 The Worldview of Estonian folk religion by Oskar Loorits was re-published. In 1997 Ivar Paulson's Old Estonian Folk Religion was reprinted and has since then served as a primary study book in the field. It seemed clear that contemporary Western scholarship, and the more conservative Estonian research with its Finno-Ugric orientation, represented alternative trends and offered different paths for the future.

During the following decades, the disciplinary and institutional basis of Estonian research on folk religion has expanded as ethnologists have joined the field. Thus, Art Leete has studied the representations of Ob-Ugrian and Samoyedic peoples in scholarly discourse (2000). He has published works on religious responses and resistance to Soviet power in Siberia, and on contemporary folk religion among the Komi (2004; Leete \& Vallikivi 2011). His colleague Laur Vallikivi at the Department of Ethnology, University of Tartu, has studied the Christian conversion of the Nenets who have joined the Baptist and Pentecostal movements (2011). Among Estonian folklorists, Aado Lintrop has also been interested in the Finno-Ugric and Siberian religions, publishing a comprehensive monograph on shamanism (1995) and another on Udmurt folk religion (2003). Ergo-Hart Västrik has studied the representation of Votian folk religion in historical sources (2007) and its expressions in contemporary culture (2008). Madis Arukask has published works on afterlife beliefs in Estonia (1998; 2011) and studied vernacular religion among the Vepsians (Arukask \& Raudalainen 2012). Taisto-Kalevi Raudalainen has been working on life-stories and religious movements among the Ingrian Finns (2004). Mare Kõiva, who has played a leading role in regenerating research in folk religion, has published works on healers, charms, magic, legends and other aspects of folk religion past and present (2007; 2011). Reet Hiiemäe has studied historical legends about the plague (1997); her recent publications include a monograph on protective magic (2012) and another on omens and predicting future (2013). Mari-Ann Remmel is an expert on local legends about holy sites and other place-lore (1998), and Mare Kalda on legends about the hidden treasures (2011). Merili Metsvahi's research has been focused on the individual as a carrier of religious traditions and on werewolf beliefs and legends (2012). Marju Kõivupuu has studied sacred places (2009), death culture (2010), folk medicine (2013) and other aspects of Estonian folk religion. Kristel Kivari is analyzing contemporary beliefs, practises and religious discourse in the 
New Age traditions (2012). Institutionally, the main folkloristic centres of research have been the Estonian Literary Museum in Tartu, with its Department of Folkloristics and Estonian Folklore Archives, and the Department of Estonian and Comparative Folklore, University of Tartu.

The current situation, as regards the range of publications, diversity of research topics and approaches, is too vast to be compressed into a brief survey. It should be noted, however, that folk religion is also being studied from the perspectives of neighboring disciplines. Thus, in religious studies Lea Altnurme has examined religious life stories (2011) and recent changes in religious orientation in Estonia from traditional Christianity towards New Age spirituality (2006); and in ethnolinguistics, Urmas Sutrop has examined the semantics and etymologies of the Estonian terminology of folk beliefs and theonyms (e.g. Sutrop 2004a; 2004b). In archaeology, Heiki Valk has studied the burial customs of Estonian medieval village graveyards and interpreted these data in the context of Christianization as a historical process (2003; 2009). He has systematically used the collections of the Estonian Folklore Archives in interpreting archaeological sources.

Many publications on folk religion have reached the international readership thanks to two academic journals: Folklore: an Electronic Journal of Folklore (published since 1996) and Journal of Ethnology and Folkloristics (since 2007), both edited in Tartu. In addition, the Estonian journal Mäetagused (published since 1996) has regularly published articles on folk religion. All three journals are free access publications in the Internet, but they also appear regularly in print. As regards general developments in research, the trend of internationalization of studies should be noted. Whereas earlier research was empirically bound to Estonian and Finno-Ugric material, contemporary scholarship rather proceeds from conceptual grounds and methodologies, sometimes finding its object in geographically distant cultures (e.g. Valk \& Lourdusamy 2007). Internationalization has also expanded the realm of doctoral studies at the University of Tartu. Thus, in 2012 Toms Kencis defended his dissertation on the disciplinary history of Latvian mythology and folk religion. It is a comprehensive and reflexive treatise on the formation and development of research during the $19^{\text {th }}$ and $20^{\text {th }}$ centuries, covering the works of leading Latvian scholars, such as Kārlis Straubergs (1890-1962), Haralds Biezais (1909-1995) and others (Ķencis 2012). In 2013 Jinseok Seo completed his work on the role of shamanism in Korean society in its inter- and intra-cultural contacts (Seo 2013). Currently, Tiina Sepp has completed her dissertation on vernacular religion and belief narratives among the pilgrims on the road to Santiago de Compostela (see Sepp 2012). 
Margaret Lyngdoh is studying contemporary beliefs, legends and rituals among the Khasis, an indigenous people of North Eastern India (Lyngdoh 2012). These dissertations are based on fieldwork, which has been a rising trend among PhD students alongside more traditional work in the folklore archives.

\section{Conceptual Developments: From Folk Religion towards Vernacular Religion}

Although folk religion (rahvausund) is one of the key concepts in these studies from the last two decades, it would be problematic to formulate for it universal definition in this heterogeneous scholarship. However, taking into consideration the long history of research discussed above, it is possible to indicate some general developments and conceptual shifts in Estonia.

We saw that during the 19th century the concept of 'folk religion' posited a strong conflict between Christianity and heathendom, and the awareness of this as a fundamental dichotomy guided folklorists in their search for ancient beliefs and religious practices. As Veikko Anttonen has noted, '“folk religion" signified a body of beliefs and practices that were inextricably interwoven with peasant culture and its oral transmission of tradition' (2004, 74). The view from above - from the perspective of Protestant intellectuals - linked Christianity with rationalism and modernization, whereas folklore represented tradition as 'modernity's otherness' (Anttonen 2005, 33): a static body of reified beliefs and behavior patterns which had been transmitted from generation to generation. Within the context of nationbuilding, however, folklore acquired a positive aura. Folk beliefs were not a body of superstitions to be eliminated, but a cultural heritage which represented indigenous traditions. Folklore became a marker of national identity, an ancient treasury (vanavara) of pre-Christian Estonia, as Jakob Hurt saw it. Attempts to use folklore recordings as windows into the distant past continued during the 20th century, and culminated in the monumental work of Oskar Loorits. Later, Soviet scholarship maintained a static view of folk belief as a set of ancient survivals that stood in contrast to Christianity and expressed resistance to change.

New scholarship during the last decades, however, has deconstructed the meaning of 'folk' as a traditional and conservative village-based community. 'Folk religion' came to denote shared beliefs and religious practices that are embedded in communities and social networks but do not have institutional bases. The sharp division between folk religion and Christianity has also 
lost its force, as it has become clear that Christian influences in folklore are not confined merely to survivals of folk Catholicism, but grow over time. As David Elton Gay has noted, 'the Christian and Finno-Ugric elements must be studied as a whole, without concern for the origin of specific beliefs' (2006, 77). Although many beliefs and religious practices were disapproved of by the Lutheran church and the Pietistic movements, it would be misleading to construct a model of two separate religious systems in 19th century, one inherently Christian and the other opposed to it. Creating the Estonian national mythology and its vernacular developments were ideologically determined cultural processes, but all the efforts to develop religious studies on this foundation have given distorted pictures.

The individualistic world of New Age spirituality, which has brought the personal dimension of religious belief to the center of attention, has also prepared the ground for a new conceptualization of the 'folk'. Instead of indicating the social basis of belonging to a group, it is being used to refer to informal channels of communication and forms of expression - vernacular, unofficial, either free from institutional control or in dialogic relationship with authoritarian discourses. Leonard Primiano's concept of 'vernacular religion' as subjectively lived and experienced religion (Primiano 1995, 44) has resonated with contemporary Estonian scholarship, as it 'highlights the power of the individual and communities of individuals to create and recreate their own religion' (Primiano 2012, 383). This 'vernacular' approach also draws on folkloristic research on genres as expressive forms, rhetorical strategies and resources of tradition. Genre as a concept has ceased to be a mere nominalist label for the classification of folklore, as nowadays it is used to refer to different modalities of expression, channels of transmitting beliefs and the verbal environment in which the supernatural is constructed. Genres represent specific outlooks and orientations to social reality (Bowman \& Valk 2012, 8). This understanding of genres has guided contemporary scholarship towards the lived world of social relations and dominant discourses, whether religious or secular. From the powerful discourses of Protestant Christianity, the Enlightenment, nation-building and Communism, Estonian society has moved to the age of quasi-scientific materialism, capitalist marketing, globalization, environmental protection and other discursive dominants. The diverse world of the new spirituality resonates with these mainstream discourses, but also offers a variety of alternatives. Folkloristics as a socially oriented discipline, with its focus on vernacular practises and verbal expression, is well placed to analyze and interpret this changing religious landscape with its renewing conceptual tools. 
Bibliography

Altnurme, Lea

2006 Kristlusest oma usuni. Uurimus muutustest eestlaste religioossuses 20. saj. II poolel. Tartu: Tartu Ülikooli Kirjastus.

2011 Changes in mythic patterns in Estonian religious life stories. - Social Compass 58: 1, 77-94.

\section{Annist, August \& Harri Moora}

1965 Teos eesti rahvausundi uurimise alalt. - Keel ja Kirjandus 8, 501-8.

\section{Annist, August}

1966 Eesti rahvausundi uurimise olukorrast. - Keel ja Kirjandus 8, 457-67.

2005 Friedrich Reinhold Kreutzwaldi 'Kalevipoeg'. Tallinn: Eesti Keele Sihtasutus.

\section{Anttonen, Pertti J.}

2005 Tradition through Modernity. Postmodernism and the Nation-State in Folklore Scholarship. Helsinki: Finnish Literature Society. (Studia Fennica Folkloristica, 15.)

\section{Anttonen, Pertti J. \& Reimund Kvideland (eds)}

1993 Nordic Frontiers: Recent Issues in the Study of Modern Traditional Culture in the Nordic Countries. Turku: Nordic Institute of Folklore.

\section{Anttonen, Veikko}

2004 Theory and Method in the Study of 'Folk Religion'. - Temenos: Nordic Journal of Comparative Religion, 39-40, 73-9.

\section{Arukask, Madis}

1998 Death and Afterwards. - Folklore: Electronic Journal of Folklore 9, 7-20.

2011 Resurrection, Revenance, and Exhumation: The Problematics of the Dead Body in Songs and Laments. - Tore Ahlbäck \& Björn Dahla (eds), Religion and the Body, 28-54. Åbo: Donner Institute for Research in Religious and Cultural History.

\section{Arukask, Madis \& Taisto-Kalevi Raudalainen}

2012 Autobiographical and Interpretative Dynamics in the Oral Repertoire of a Vepsian Woman. - Marion Bowman \& Ülo Valk (eds), Vernacular Religion in Everyday Life: Expressions of Belief, 104-39. Sheffield, Bristol CT: Equinox.

\section{Berlin, Isaiah}

1997 Vico and Herder: Two Studies in the History of Ideas. New York: Vintage Books. 


\section{Bowman, Marion \& Ülo Valk}

2012 Introduction: Vernacular religion, generic expressions and the dynamics of belief. - Marion Bowman \& Ulo Valk (eds), Vernacular Religion in Everyday Life: Expressions of Belief, 1-19. Sheffield, Bristol, CT: Equinox.

\section{Eisen, Matthias Johann}

1909-1911 Eestlaste sugu I-II. E.K.S. Tartu: Rahwakirjanduse Toimekonna Kirjastus.

1919 Eesti mütoloogia. Tallinn: Eestimaa Kooliõpetajate Vastastiku Abiandmise Seltsi raamatukauplus.

1920a Eesti uuem mütoloogia. Tallinn: K/Ü 'Rahvaülikool'.

1920b Esivanemate ohverdamised. Tallinn: Varrak.

1926 Eesti vana usk. Eesti Kirjanduse Seltsi Toimetised, 21. Tartu: Eesti Kirjanduse Selts.

1996 Esivanemate ohverdamised. Tallinn: Mats.

\section{Faehlmann, Friedrich Robert}

1999 Teosed I. Tartu: Eesti Kirjandusmuuseum.

\section{Gay, David Elton}

2006 Christianity as a Problem in Folk Cultural Studies. - Tautosakos darbai XXXI, 74-81. Vilnius: The Institute of Lithuanian Literature and Folklore.

\section{Hagu, Paul}

1975 Setu viljakusjumal Peko. - Keel ja Kirjandus 3, 166-72.

\section{Hiiemäe, Mall}

1981-1999 Eesti rahvakalender II-VIII. Tallinn: Eesti Raamat.

1998 Der estnische Volkskalender. Helsinki: Academia Scientiarum Fennica. (Folklore Fellows' Communications, 268.)

\section{Hiiemäe, Reet}

1997 Eesti katkupärimus. Tartu: EKI folkloristika osakond, EKM Eesti Rahvaluule Arhiiv. (Monumenta Estoniae Antiquae, II.)

2012 Kaitsemaagia eesti rahvausundis. Tallinn: Pegasus.

2013 Ended ja ennustamised eesti rahvausundis. Tallinn: Pegasus.

\section{Hupel, August Wilhelm}

1963 Beitrag zu den Nachrichten von den Esten und Letten 1781. - Eduard Laugaste, Eesti rahvaluuleteaduse ajalugu: valitud tekste ja pilte, 84-9. Tallinn: Eesti Riiklik Kirjastus.

\section{Hurt, Jakob}

1888 Kümnes aruanne Eesti wanawara korjamisest ja keelemurrete uurimisest. - Olevik, 37, 12.09, 1.

1989 Mida rahvamälestustest pidada. Artiklite kogumik. Tallinn: Eesti Raamat. 


\section{Jaago, Tiiu}

2005 Jakob Hurt: The Birth of Estonian-language Folklore Research. Kristin Kuutma \& Tiiu Jaago (eds), Studies in Estonian Folkloristics and Ethnology: A Reader and Reflexive History, 45-64. Tartu: Tartu University Press.

2009 Lugu ja sündmus jutu-uurimises: situatsioonianalüüsist kontekstianalüüsini. - Mäetagused 43, 125-44.

\section{Jaanits, Lembit}

1961 Jooni kiviaja uskumustest. - Ea Jansen (ed.), Religiooni ja ateismi ajaloost Eestis. Artiklite kogumik II, 5-70. Tallinn: Eesti Riiklik Kirjastus.

\section{Jakobson, Carl Robert}

1867 Kooli Lugemise raamat. Esimene jagu. Tartu: H. Laakmann.

\section{Järv, Risto}

2001 Kristfrid Gananderi 'Mythologia Fennica' saksakeelsest tõlkest. - Keel ja Kirjandus 3, 173-80.

\section{Kalda, Mare}

2011 Rahvajutud peidetud varandustest: tegude saamine lugudeks. Tartu: University of Tartu Press. (Dissertationes folkloristicae Universitatis Tartuensis, 15.) http://dspace.utlib.ee/dspace/bitstream/handle/10062/17237/ kalda_mare.pdf?sequence $=1$

\section{Kencis, Toms}

2012 A disciplinary history of Latvian mythology. Tartu: University of Tartu Press. (Dissertationes folkloristicae Universitatis Tartuensis, 19.) $<$ http://dspace.utlib.ee/dspace/bitstream/handle/10062/26720/kencis_toms.pdf?sequence $=1>$

\section{Kikas, Katre}

2013 Ajakirjandus Jakob Hurda ja Matthias Johann Eiseni rahvaluulekogumise mõtestajana. - Keel ja Kirjandus 5, 333-50.

\section{Kivari, Kristel}

2012 Energy as the Mediator Between Natural and Supernatural Realms. - Journal of Ethnology and Folkloristics 6 (2), 49-68.

\section{Krohn, Julius}

1894 Suomen suvun pakanallinen jumalanpalvelus: Neliä lukua Suomen suvun pakanallista jumaluus-oppia. Helsinki: Suomalaisen Kirjallisuuden Seura.

\section{Krohn, Kaarle}

1915 Suomalaisten runojen uskonto. Helsinki: Suomalaisen Kirjallisuuden Seura. 


\section{Kuutma, Kristin}

2005 Matthias Johann Eisen: A Collector and Publisher of Narratives. Kristin Kuutma \& Tiiu Jaago (eds), Studies in Estonian Folkloristics and Ethnology: A Reader and Reflexive History, 79-99. Tartu: Tartu University Press.

\section{Kõiva, Mare}

2011 Eesti loitsud. Tallinn: Pegasus.

2007 Through the Ages: Folklore as a Common Expression of Lingual, Figurative, Emotional and Mental Memory. Tartu: EKM Teaduskirjastus. (Sator, 5.) <http://www.folklore.ee/rl/pubte/ee/sator/sator5/>

\section{Kõivupuu, Marju}

2009 Natural sacred places in landscape: An Estonian model. - S. Bergmann \& P. M. Scott \& M. Jansdotter Samuelsson \& H. Bedford-Strohm (eds), Nature, Space and the Sacred. Transdisciplinary Perspectives, 223-34. Farnham, Surrey; Burlington, VT: Ashgate Publishing.

2010 Surmakultuuri suundumustest tänapäeval. - Usuteaduslik Ajakiri 1, 105-29.

2013 Igal hädal oma arst, igal tõvel ise tohter. Sissevaade Eesti rahvameditsiini. Tallinn: Varrak.

Laagus, Aino

1974 Situatsioonianalüüsist folkloristikas. - Keel ja Kirjandus 7, 404-12.

Laar, Mart

2010 Rahvuslus ja eelärkamisaeg. - Sulev Vahtre, et al. (eds), Eesti ajalugu V. Pärisorjuse kaotamisest Vabadussõjani, 219-33. Tartu: Ilmamaa.

\section{Laugaste, Eduard}

1963 Eesti rahvaluuleteaduse ajalugu: valitud tekste ja pilte. Tallinn: Eesti Riiklik Kirjastus.

1977 Eesti rahvaluule. Tallinn: Valgus.

Leete, Art

2000 Põhjarahvad antiigist tänapäevani. Tartu: Eesti Rahva Muuseum. (Eesti Rahva Muuseumi sari, 3.)

2004 Folk Religion and Identity: A Study of Ethnic Conflicts in Siberia. Temenos: Nordic Journal of Comparative Religion 39-40, 235-45.

\section{Leete, Art \& Laur Vallikivi}

2011 Imitating Enemies or Friends: Comparative Notes on Christianity in the Indigenous Russian Arctic during the Early Soviet Period. - Asian Ethnology, 70 (1), 81-104.

\section{Lintrop, Aado}

1995 Samaaniraamat. Tartu: Ilmamaa.

2003 Udmurdi usund. Tartu: Eesti Rahva Muuseum. (Eesti Rahva Muuseumi sari, 5.) 


\section{Loorits, Oskar}

1926-1928 Liivi rahva usund I-III: mit einem Referat: Der Volksglaube der Liven. Tallinn: Tallinna Eesti Kirjastus-Ühisus.

1932a Estnische Volksdichtung und Mythologie. Tartu: Akadeemiline Kooperatiiv.

1932b Eesti rahvausundi maailmavaade. - Elav Teadus 12. Tartu: Eesti Kirjanduse Seltsi Kirjastus.

1949-1957 Grundzüge des estnischen Volksglaubens, Bd. 1-3. Uppsala: Lundequistska Bokhandeln \& Köpenhamn: Munksgaard.

1990 Eesti rahvausundi maailmavaade. Tallinn: Perioodika.

2000a Liivi rahva usund IV-V. Tartu: Eesti Kirjandusmuuseum.

2000b Eesti esiajaloo keerdküsimusi. - Meie, eestlased, 309-35. Tartu: Ilmamaa. (Eesti mõttelugu, 35.)

\section{Lätt, Selma}

1970 Eesti rahvakalender I. Tallinn: Eesti Raamat.

\section{Lyngdoh, Margaret}

2012 The Vanishing Hitchhiker in Shillong Khasi Belief Narratives and Violence Against Women. -Asian Ethnology 71 (2), 207-24.

\section{Masing, Uku}

1995 Eesti usund. Tartu: Ilmamaa.

2004 Keelest ja meelest. Taevapõdra rahvaste meelest ehk juttu boreaalsest hoiakust. Tartu: Ilmamaa.

\section{Metsvahi, Merili}

2011 Die Frau als Werwölfin (AT 409) in der estnischen Volkstradition. Willem de Blecourt \& Christa Agnes Tuczay (eds) - Tierverwandlungen. Codierungen und Diskurse, 193-219. Tübingen: Francke Verlag.

\section{Paulson, Ivar}

1958 Die primitiven Seelenvorstellungen der nordeurasischen Völker. Eine religionsethnographische und religionsphänomenologische Untersuchung. Stockholm. (The Ethnographical Museum of Sweden, Stockholm. Monograph Series, 5.)

1962a Die Religionen der finnischen Völker. - Die Religionen Nordeurasiens und der amerikanischen Arktis, 147-282. Stuttgart: W. Kohlhammer. (Religionen der Menschheit, 3.)

1962b Die Religionen der nordasiatischen (sibirischen) Völker. -Die Religionen Nordeurasiens und der amerikanischen Arktis, 5-147. Stuttgart: W. Kohlhammer. (Religionen der Menschheit, 3.)

1971 The old Estonian folk religion. Bloomington: Indiana University; The Hague: Mouton.

\section{Perno Postimees}

1866 Mõnni sõnna Eestirahwa eeswannemattest. - Perno Postimees 19.01, 1. 


\section{Primiano, Leonard Norman}

1995 Vernacular Religion and the Search for Method in Religious Folklife. - Western Folklore, 54 (1), 37-56.

2012 Afterword: Manifestations of the religious vernacular: Ambiguity, power, and creativity. - Marion Bowman \& Ülo Valk (eds), Vernacular Religion in Everyday Life: Expressions of Belief, 382-94. Sheffield, Bristol, CT: Equinox.

\section{Raudalainen, Taisto-Kalevi}

2004 The Traits of Cultural Contacts Between Orthodox and Lutheran Commemoration Practices Among Ingrian Finnish Women. - Folklore: An electronic journal of folklore 28, 57-90.

\section{Remmel, Mari-Ann}

1998 Hiie ase. Hiis eesti rahvapärimuses. Tartu: Eesti Kirjandusmuuseum.

\section{Runnel, Pille}

2000 Saatesõna. Gustav Ränk, - Müüt ja ajalugu, 433-9. Tartu: Ilmamaa. (Eesti mõttelugu, 32.)

\section{Ränk, Gustav}

1949 Die Heilige Hinterecke im Hauskult der Völker Nordosteuropas und Nordasiens. Helsinki: Academia Scientiarum Fennica. (Folklore Fellows' Communications, 137.)

1996 (1949) Vana-Eesti rahvas ja kultuur. Tartu: Ilmamaa.

1997 Autorist ja tema tööst. - Ivar Paulson, Vana eesti rahvausk, 5-9. Tartu: Ilmamaa.

2000 Usund vaimsuse mõõdupuuna. - Mü̈̈t ja ajalugu, 235-42. Tartu: Ilmamaa. (Eesti mõttelugu, 32.)

\section{Selart, Anti}

2013 Gehören die Esten zum Westen oder Osten? Oskar Loorits zwischen friedvollen Finnen und aggressiven Germanen. - Alexander Drost \& Michael North (Hg.) Die Neuerfinding des Raumes: Grenzüberschreitungen und Neuordnungen, 143-59. Köln, Weimar, Wien: Böhlau Verlag.

\section{Selirand Jüri}

1961 Muistsed matmiskombed eestlaste usundi ja ristiusu-vastase võitluse kajastajana. - Ea Jansen (ed.), Religiooni ja ateismi ajaloost Eestis. Artiklite kogumik II, 71-93. Tallinn: Eesti Riiklik Kirjastus.

\section{Seo, Jinseok}

2013 The role of shamanism in Korean society in its inter-and intra-cultural contacts. Tartu: University of Tartu Press. (Dissertationes folkloristicae Universitatis Tartuensis, 20.)

\section{Sepp, Tiina}

2012 Stories of Santiago pilgrims: Tradition through creativity. - Marion 
Bowman \& Ülo Valk (eds), Vernacular Religion in Everyday Life: Expressions of Belief, 301-27. Sheffield, Bristol, CT: Equinox.

\section{Sutrop, Urmas}

2004a Eesti keele maailmapildist: meel, hing ja vaim. - Mäetagused 24, 99-108. 2004b Taarapita - the Great God of the Oeselians. - Folklore: An electronic journal of folklore 26, 27-64.

Tedre, Ülo

1965 Eesti rahva, tema keele, rahvaluule ja kirjanduse algupärast ja olemusest. - A. Vinkel (ed.), Eesti kirjanduse ajalugu, I köide: esimestest algetest XIX sajandi 40-ndate aastateni, 17-36. Tallinn: Eesti Raamat.

1996 Matthias J. Eisen rahvausundi uurijana. - Matthias Johann Eisen, Esivanemate ohverdamised, 170-7. Tallinn: Mats.

\section{Valk, Heiki}

2003 The Christianisation of Estonia and Changes in Burial Customs. - Offa, 58. Neumünster: Wachholz Verlag Neumünster, 215-22.

2009 Sacred natural places of Estonia: regional aspects. - Folklore: An electronic journal of folklore, 42, 45-66.

Valk, Ülo

2001 The Black Gentleman: Manifestations of the Devil in Estonian Folk Religion. Helsinki: Academia Scientiarum Fennica. (Folklore Fellows' Communications, 276.)

\section{Valk, Ülo \& S. Lourdusamy}

2007 Village Deities of Tamil Nadu in Myths and Legends: the Narrated Experience. - Asian Folklore Studies 66 (1-2), 179-99.

\section{Vallikivi, Laur}

2011 What does matter?: Idols and icons in the Nenets tundra. - Journal of Ethnology and Folkloristics, 5 (1), 75-95.

\section{Undusk, Jaan}

2008 Baltisaksa kirjanduse breviaar: põhilaad, erijooned, esindajad. - R. Undusk (ed), Rahvuskultuur ja tema teised, 93-120. Tallinn: Underi ja Tuglase Kirjanduskeskus. (Collegium litterarum, 22.)

\section{Viluoja Eha}

1978 Sõnamaagia kodukäija tõrjes. - Ü. Viks \& V. Pall (eds) Sõnast tekstini, 117-135. Tallinn: Eesti NSV Teaduste Akadeemia.

\section{Västrik, Ergo-Hart}

2005 Oskar Loorits: Byzantine Cultural Relations and Practical Application of Folklore Archives. - Kristin Kuutma \& Tiiu Jaago (eds), Studies in Estonian Folkloristics and Ethnology: A Reader and Reflexive History, 203-15. Tartu: Tartu University Press. 
2007 Vadjalaste ja isurite usundi kirjeldamine keskajast 20. sajandi esimese pooleni: alliktekstid, representatsioonid ja tõlgendused. Tartu: Tartu Ülikooli Kirjastus. (Dissertationes folkloristicae Universitatis Tartuensis, 9.) $<$ https://dspace.utlib.ee/dspace/bitstream/handle/10062/3458/vastrik_ergo-hart.pdf?sequence $=1>$

2008 Votian Village Feasts in the Context of Russian Orthodoxy. - Journal of Ethnology and Folkloristics 2 (1), 99-122. 
